\title{
Is there an association between hypothyroidism and COVID 19?
}

\section{A preliminary report}

\author{
Satvinder Singh Bakshi (D) - Vinoth Kumar Kalidoss
}

Received: 11 November 2020 / Accepted: 13 January 2021 / Published online: 3 February 2021

(C) Springer-Verlag GmbH, AT part of Springer Nature 2021

Dear editor,

The coronavirus epidemic has been declared as a public health emergency and has affected millions of people worldwide. There is evidence to suggest that people with comorbidities like diabetes, heart disease, asthma, hypertension, and cancer are more susceptible, have increased morbidity and mortality associated with the infection [1]. The evidence regarding hypothyroidism or thyroid disorders is still conflicting with some studies pointing out a correlation [2] and others refuting it [3].

We would like to share our experience in this regard. Since the beginning of the pandemic, our center has tested more than 1000 suspected cases of coronavirus disease 2019 (COVID 19) infection. The test is carried out using throat/nasal swabs and tested using RT-PCR for the viral genes. A total of 456 positive cases were detected. Among the suspect patients, 24 patients had hypothyroidism and were on replacement therapy. Of these patients 21 were reported to have COVID 19 infection through RT-PCR, this included 18 females and 3 males. Out of these 21 patients, 14 patients had other comorbidities like diabetes [2], hypertension [5] and other comorbidities [1], the other 7 had hypothyroidism alone. The average age of hypothyroid patients who were COVID 19 positive was 44.9 years (Table 1 ).

Both Dr Satvinder Singh Bakshi and Dr Vinoth Kumar Kalidoss have contributed equally to the manuscript.

Associate professor of ENT Dr S. S. Bakshi, MS, DNB $(\bowtie)$

Dept of ENT and Head \& Neck Surgery, AIIMS Mangalagiri, 522503, Guntur, Andhra Pradesh, India

saty.bakshi@gmail.com

Dr. V. K. Kalidoss, MD MPH

Department of Community and Family Medicine, AIIMS

Mangalagiri, 522503, Guntur, Andhra Pradesh, India vinob4u@gmail.com
There are a few studies that have explored the development of hypothyroidism during or after the COVID infection. A study by Chen et al. [4] found that out of 50 patients with a COVID infection, $56 \%$ had lower than normal TSH (Thyroid Stimulating Hormone) levels, which was statistically significant. They also found that the degree of decrease of TSH and TT3 (Total Triiodothyronine) correlated positively with the severity of the disease. The possible mechanism can be due to the release of systemic proinflammatory cytokines or direct viral effects on the pituitary or thyroid gland. Another study done by Dosi et al. [5] found $2.7 \%$ hypothyroidism in 365 COVID patients, this increased to $3.6 \%$ in severely ill patients and patients needing mechanical ventilation $4.085 \%$. They also found that hypothyroidism was the third common comorbidity among COVID 19 patients.

Table 1 Comparison of the presence of hypothyroidism and other comorbidities in COVID 19 suspect and positive cases

\begin{tabular}{|c|c|c|c|c|}
\hline S. No & Parameter & $\begin{array}{l}\text { COVID } 19 \\
\text { Suspect } \\
(n=24)\end{array}$ & $\begin{array}{l}\text { COVID } 19 \\
\text { Positive } \\
(n=21)\end{array}$ & $\begin{array}{l}\text { COVID } 19 \\
\text { Negative } \\
(n=3)\end{array}$ \\
\hline 1 & $\begin{array}{l}\text { Age (years, mean and } \\
\text { SD) }\end{array}$ & $43(11.68)$ & $44.90(11.41)$ & $33.33(9.60)$ \\
\hline 2 & Male & 3 & 3 & 0 \\
\hline 3 & Female & 21 & 18 & 3 \\
\hline 4 & Hypothyroidism alone & 8 & 7 & 1 \\
\hline 5 & Hypothyroid + diabetes & 2 & 2 & 0 \\
\hline 6 & $\begin{array}{l}\text { Hypothyroid + hyper- } \\
\text { tension }\end{array}$ & 5 & 5 & 0 \\
\hline 7 & $\begin{array}{l}\text { Hypothyroid + diabe- } \\
\text { tes+ hypertension }\end{array}$ & 8 & 6 & 2 \\
\hline 8 & $\begin{array}{l}\text { Hypothyroid + other } \\
\text { comorbidities }\end{array}$ & 1 & 1 & 0 \\
\hline
\end{tabular}


Although our sample size is small and the cause for hypothyroidism has not been assessed, we would still like to point out the increased association of COVID infection and hypothyroidism in our patients. This relationship and the effect of hypothyroidism on the severity of infection and prognosis can be explored in further studies.

Conflict of interest S. S. Bakshi and V. K. Kalidoss declare that they have no competing interests.

\section{References}

1. Sanyaolu A, Okorie C, Marinkovic A, et al. Comorbidity and its impact on patients with COVID-19. SN Compr Clin Med. 2020; https://doi.org/10.1007/s42399-020-00363-4.
2. Hariyanto TI, Kurniawan A. Thyroid disease is associated with severe coronavirus disease 2019 (COVID-19) infection. Diabetes Metab Syndr. 2020;14(5):1429-30. https://doi. org/10.1016/j.dsx.2020.07.044.

3. Dworakowska D, Grossman AB. Thyroid disease in the time of COVID-19. Endocrine. 2020;68(3):471-4. https://doi. org/10.1007/s12020-020-02364-8.

4. Chen M, Zhou W, Xu W. Thyroid function analysis in 50 patients with COVID-19: a retrospective study. Thyroid. 2020; https://doi.org/10.1089/thy.2020.0363.

5. Dosi R, Jain G, Mehta A. Clinical characteristics, comorbidities, and outcome among 365 patients of coronavirus disease 2019 at a tertiary care centre in central India. J Assoc Physicians India. 2020;68(9):20-3.

Publisher's Note Springer Nature remains neutral with regard to jurisdictional claims in published maps and institutional affiliations. 